\title{
Christianity and the Loss of the Messiah
}

\author{
Wolfgang Treitler \\ University of Vienna, Vienna, Austria
}

\begin{abstract}
This article deals with the fundamental changes that happened to become real within the first three centuries of Christianity and turned the self-description of Christianity as a Messianic movement and community inconsistent. The main reason, as I argue, was because the Messianic confessions and expectations witnessed by early Jewish-Christian writings such as Paul's letters (esp. to the Romans) and the so-called Didache, a rule of a Jewish-Christian community, did not come true, since time went on, the Messiah did not reappear and, most of all, the Roman Empire remained solid. This gave way to a fundamental change caused by two historical developments and their theological effects: the slow, but steady slide of Messianic hopes as times went on and the Messiah Jesus did not reappear or change history; and the development of pagan-Christian communities approaching Jesus by the means of pagan interpretations of Jesus Christ. Eventually, these pagan interpretations made it in the 4th cent. to set up a creed that did not only suspend anything Messianic in respect of Jesus, but replace these Christian-Jewish ideas and hopes by declaring Jesus being God-man. This declaration was the end of any real Messianic hope and the end of the Jewish Jesus for many centuries. Christianity has lost its Messiah and was turned into a dogmatic religion. Facing this development it is evident that Christianity has to exceed its own dogmatic limits in respect of Jesus.
\end{abstract}

Keywords: Messiah, Christology, Paul, Didache, Jewish-Christian movements, religion

\section{Christian Self-contradiction}

Self-descriptions of religious communities are very informative. They offer a self-expression as short as possible about the contents of faith, the ways of believing, and sometimes even about their bases, i.e., where they have been coming from. This is a major step of rationalizing itself as a religious community, and it implies that everything irrational and even extreme occurrences such as religious madness and terror are considered either a misshape of the religious development as something not belonging to it, or something non-irrational in a strict sense, a real mystery, a secret only a few initiates have access to who are able to rationalize it in a religious way. Thus, each self-description concentrates a specific religious consciousness and demands a specific awareness.

This goes for the leading monotheistic traditions, too. Judaism can find its fundamental meaning in a story of the first book of the Tora. When Lea, Jakob's wife, became pregnant once more and for the last time, she said: “"This time I will praise the Lord'. Therefore she called his name Judah" (Gen 29.35). Judah of Yehuda derives from the Hebrew word lehadot ${ }^{1}$ meaning to thank someone. The name of Yehuda remained as a

Wolfgang Treitler, Professor, Department of Basic Theological Research, The Catholic-Theological Faculty, University of Vienna.

1 להות (lehadot) has the same leading consonants as the word and name build the root of all derives in connection with the meaning of thank. 
political ascription to the land surrounding Jerusalem, the only Jewish entity after Israel had been extinguished in 722 BCE. Since then Yehuda has been referring to the people of the eternal covenant, although it must be stressed that this was not the only one and exclusive ascription. ${ }^{2}$ This people being constituted by being thankful projected its attitude back to the stories of the very beginning of mankind. Even the first man ever who has been considered very ambivalent by the rabbinic tradition ${ }^{3}$ started his way of life not by lamenting or begging of his creator, the only a sole God, but by thanking him for Shabbat, because it was Schabbat itself that saved Adam from nemesis, i.e., from death right at the beginning after Adam's incomprehensible lapse. ${ }^{4}$ Being thankful is part of man as such, and Judaism established this very human attitude again.

The word Islam means peaceful submittal to Allah's will. ${ }^{5}$ God's will is mediated by his prophet Muhammad and the so-called Sharia, the "path to the drinking trough". ${ }^{6}$ Both the prophet and the Sharia show the way if Islam. These principles expressed in the word Islam were not touched or changed by the changes taking place immediately after Muhammad's death. ${ }^{7}$ Islam remained a strictly monotheistic religion in the same way as Judaism does, but beyond that it considers itself the fulfillment of divine revelation and religious history and therefore claims to enforce this fulfillment by missionary action or - according to Muslim self-concept ${ }^{8}$ - by regaining the people and the world as far as they have gone astray and lost the true path. For everything belongs to Allah. This concept is the basis for the so-called Jihad, the holy struggle for Allah. That is why Islam has an extensive and universal claim right from its beginning until now; the demand goes for everybody to return to the divine truth of Islam.

Christianity's meaning is somewhat different compared to Judaism and Islam. It does not refer to an attitude like thankfulness or submittal, but to a confession and a commitment, to the confession of Jesus as Messiah and to a commitment of belonging to him and his community. It is striking to see that such an attribution appeared for the first time in order to identify former pagan believers as Christians (Act 11.26), but not in order to name Jews believing in Jesus as Messiah. This happened in Antiochia. Apart from what these pagans might have intended when they confessed Jesus as Messiah, proves this fact a substantial change differing from Jewish and Muslim tradition, because from now on the center of Christianity was not an attitude any longer, but a person. This caused the turn from a theocentric attitude to a Christocentric commitment. The very heart of this kind of Christianity became the belief in Christ. Neither Judaism nor Islam developed something similar. Moses is important, of course, as king of the prophets; Muhammad is important as the fulfillment of the prophetic tradition. But none of them has been turned into a God. It is exactly this unique Christian development that eventually led to the idea contradicting Jewish and Muslim fundamental belief that a man was in fact God himself - the core of Nicene Creed declared in the year 325. ${ }^{9}$ This creed brought an end

\footnotetext{
${ }^{2}$ Yehuda could also have been named Israel, Jacob, and Josef. Israel is a synonym for Jacob (Gen 32.29), and Joseph, Jacob's son, stands for Israel or Yehuda in Ps 81.

3 bT Sanh 38a-b.

4 Die Sagen der Juden. Gesammelt und bearbeitet von Micha Josef bin Gorion, Köln: Parkland Verlag 1997, 88.

${ }^{5}$ Weltsch Robert / Kirschner Bruno, Art Islam, in: Jüdisches Lexikon. Ein enzyklopädisches Handbuch des jüdischen Wissens in vier Bänden. Begründet von Dr. Georg Herlitz und Dr. Bruno Kirchners. Mit über 2000 Illustrationen, Beilagen, Karten und Tabellen. Band III, Frankfurt/Main: Athenäum Verlag 1987, 50-54.

${ }^{6}$ Schall Anton, Art. Islam I, in TRE 16, 315-336, hier 334.

${ }^{7}$ Heiler Friedrich, Die Religionen der Menschheit. Herausgegeben von Kurt Goldammer. Mit 98 Abbildungen, Stuttgart: Philipp Reclam jun. ${ }^{5} 1991,502-505$.

8 Ye'or Bat, Europa und das kommende Kalifat. Der Islam und die Radikalisierung der Demokratie. Übersetzung, Hintergründe und Kommentierung von Peter Raddatz, Berlin: Duncker \& Humblot 2013, 7.

${ }^{9}$ DH 125.
} 
to Christian arguments about the position of Jesus Christ in connection ton God. Arius and his followers wanted to keep Christ being man by heart, even if they altered the usual anthropological constitution of man slightly $^{10}$; they also kept the idea that Christ was singled out by God right from the real beginning of his life through God's grace. But they did not go beyond that and denied his being God. For how can anyone who was born, who lived as a man, and died in the end, be God or at least of the same divine substance as God? The opponents of Arius and his school damned these thoughts and declared it a heresy. There were attempts of reconciliation after the Council between the dogmatic theologians and bishops on the one side and Arius on the others, and they might have led to accepting or integrating some parts of Arius's Christology. But they failed in the end because of Arius's death in $336 \mathrm{CE} .^{11}$

Nicaea marked the decisive and final legitimation of the turnaround that pagan Christianity had evolved in respect of Christology that fulfilled three main issues: It was compatible with pagan ideas of a real God-man unity, it was helpful for the Roman Empire to reestablish its political unity under an Emperor who himself was not far from being elected by divine power, and it founded and fixed the fundamental demarcation between Jewish non-believers and Christianity. By doing this the self-description of the early Christians became at least disputable, if not suspicious. These pagan Christians in Antiochia believed in Jesus as Messiah, and this was an idea enrooted in Jewish tradition. In turn, Nicaea did not think of Christ as Messiah, but of a God-man, and this was an idea enrooted in the pagan world (Vermes, 2012, p. 147) and meaning something quite different. The Creed of Nicaea has not a single hint of Israel's Messiah, but is a composition of declarations of a strong and unbreakable identity of the divine Father and the divine Son.

By doing this, Nicaea turned away from the Jewish Messiah and replaced him by the God-man, as Christianity has replaced Judaism. From now on Christology has not been asking for the Messiah, but for the identity of the God-man, and the term Christ was no longer a Greek synonym for Messiah, but it stressed Jesus's divinity. While the former self-designation of Christianity referred to the Jewish Messiah, the doctrine from the 4th century onwards dissolved him and abandoned its short self-description.

This fundamental and crucial change was not a mere invention and did not happen out of nothing. It was simply impossible that many generations after Paul could still have kept the Messianic fever he was driven by apart from the fact that the Greek scholars hardly knew what a Messiah really stood for. The victory of the Antiochian Christians, whose predecessors were not in Israel, but pagans in Antiochia, led to the abandonment of the Messiah Jesus. This fact fits to common experiences. The Messiah has not returned, as Paul assured some of his communities; and even if Constantine might have had a vision of Christ during his battle for Roman leadership in $312 \mathrm{CE}^{12}$, the scholars had their doubts if history and fate were really conducted by Christ. They saw and knew that it was not God's messianic Kingdom ruling over the peoples, but the Romans who were in power in these days as well as at the time when under one of their governors Jesus was hanged on the cross.

This is the malaise of Jesus the Messiah and Christianity named after him. The times remained as hard as ever and sometimes even turned worse - in a very twofold paradoxical way, because after Jesus it became

\footnotetext{
${ }^{10}$ Lippl Josef, Athanasius der Große, in: Athanasius, Vier Reden gegen die Arianer. Vier Briefe an Serapion. Brief an Epiktet, Kempten-München: Kösel o.J., V-XXXIX, bes. XXXI; de Clercq V. C., Art. Arianism, in: New Catholic Encyclopedia. Second Edition. Vol. 1, Detroit u. a.: Thomson-Gale 2003, 660-664, esp. 660.

${ }^{11}$ de Clercq V. C., Art. Arius, in: New Catholic Encyclopedia. Second Edition. Vol. 1, Detroit u. a.: Thomson-Gale 2003, 685f.

${ }^{12}$ Hall Stuart George, Art. Konstantin I., in TRE 19, 489-500, bes. 490; Stephenson Paul, Constantine. Unconquered Emperor, Christian Victor, London 2009.
} 
possible and sometimes even useful to execute violence and terror in his name in order to subdue non-believers (Klinghoffer, 2005, pp. 186-190), and Christian violence did not spread just by chance, but it was directed mainly at Jesus' own community, the Jewish people. ${ }^{13}$ This fact deepened Christian self-contradiction: Christianity called itself according to the Messiah it actually abandoned and sit in judgment on the Jewish community in the name of Christ whose Jewishness has been ignored in every Christian-dogmatic teaching between the 4th and the 8th century. In the end, Christianity did not miss the Messiah any longer.

This is the crucial point when it comes to Jesus as Messiah. Disguised of his Jewishness he did not change the situation of his oppressed people, but became the main ignition of anti-Jewish sentiments within Christianity indicated by many patristic theologians and their assessment of Jews as being unfaithful, viperish, and murderous. ${ }^{14}$ These ascriptions were enrooted in the patristic Christology. No wonder that Jesus's being Messiah given up by Christian scholars was either not acknowledged beyond Christian border lines. Hence, two assumptions can be made:

1. The commitment to Jesus being Messiah has been de facto abandoned by the appearance and the development of pagan Christianity. It was this way of Christianity that developed itself as a firm and stable community that in itself revoked the early messianic commitment by the plain fact that no religion could have evolved, if Jesus was the final Messiah. History would have ended. The pagan Church that was able to establish strong links to the Roman Emperors, developed a sophisticated dogmatic of Jesus as God-man absorbing and eliminating the Jewish Messiah from Nazareth. The outcome was clear: Christians could deny the Christ, i.e., the Messiah; whenever someone tended to neglect Jesus as Messiah - an idea hardly ever adopted, proving that the Messiah already got lost in Christianity -, no condemnation occurred. But if a Christian had serious doubts about Jesus' being God-man, he was excommunicated as a heretic. So what was the meaning of Jesus as Messiah within the Christological dogmatic? It just faded away.

2. This was complemented by the history after Jesus. It refuted Jesus' being the Davidic Messiah completely, even if it was not quite clear what a Davidic Messiah was like, since different views existed in Israel's Holy Scriptures, and they existed "unrelatedly and heterogeneously side by side". ${ }^{15}$ Israel was neither liberated nor came the world to peace; neither was the Temple erected again (which was still there at Jesus' times) nor did come the Kingdom of God to reality; neither were the dead resurrected nor did time come do its definite end.

Hence, it was no wonder that as time passed the Messiah from Galilee was concealed within Christianity more and more. And one should wonder even less that the Jewish communities Jesus belonged to could not and would not affirm him as Davidic Messiah. In history Jews were often faced by anti-messianic violence committed by those who pretended to believe in Christ. Basis of the violence were often countless rumors, suspicion, polemic, accusations, agitating rhetoric, and attacks creating an atmosphere that gave the Jews free to being extinguished. The Shoa was the peak of a hatred against Jews Christians have been maintaining, and they handed it down from one generation to the next by preachers, teachers, and theologians who pretended to do nothing else but explain true Christian faith and teaching and live according to it. Hunting Jews matched

\footnotetext{
${ }^{13}$ Harink Douglas, Jewish Priority, Election, and the Gospel, in: Rudolph David / Willits Joel (Hg.), Introduction tot he Messianic Judaism. Its Ecclesial Context and biblical Foundation, Zondervan: Grand Rapids 2013, 273-281, bes. 280.

${ }^{14}$ Schreckenberg Heinz, Die christlichen Adversus-Judaeos-Texte und ihr literarisches und historisches Umfeld (1.-11. Jh.), Frankfurt/Main: Peter Lang 1995, 227-378.

${ }^{15}$ Scholem Gershom, Die Krise der Tradition im jüdischen Messianismus, in: Ders., Judaica 3. Studien zur jüdischen Mystik, Frankfurt/Main: Suhrkamp Verlag 1973, 152-197, bes. 154.
} 
well with loving Christ, killing Jews could go along with praying to Jesus min a devoted manner, and burning a representative figure of Judas during the time of the Holy Week fit to celebrating on Good Friday that the blood of the God-man has redeemed man from God's curse against the sinner. ${ }^{16}$ The Christian God-man did not change any of these conditions Jews had to face. All these effects of Christian doctrine and attitude did not stem from a lunatic fringe of Christianity, but it derived right from the rootstock of pagan-Christian orthodoxy that has been prevailing in the fields of logic, semantic, and politics.

Here we can find Christian self-contradiction: The Christian commitment to Christ got rid of the Jewish Messiah and simultaneously developed a growing antipathy to Jews and Judaism frequently leading to plain hatred. This hatred was the main reason why these Christians were not aware any longer that their hatred also turned against the Messiah of the early messianic Jews. ${ }^{17}$ It is this antipathy that construed Jews as enemies of Christ and his Church because of a subcutaneous and very fundamental Christian problem that has been the core of the existence of Christian religion: Such a religion could have never been brought to reality, if Jesus was the Davidic Messiah proclaimed by Matthew. Time went on, and it did not turn to a Messianic age. So why should Jews believe in Jesus as Davidic Messiah? The fact of the development of a Christian religion as well as history is against this commitment.

\section{The Jewish Nay Against the Christian Nay}

The pagan Christian revision of the Messianic topic led to the Council of Nicaea that was determined to a teaching about Jesus Christ as God-man, a teaching incompatible with Jewish tradition. Later on this kind of pagan Christian teaching which was declared to be the only standard of Christology and theology deepened the gap between Christianity and Judaism and generated more and more problems to keep the Christological demand that Jesus was the fulfillment of God's revelation and of men's history. Jesus' being man was to volatize as time went on, it was absorbed by his divine nature mysteriously cloaked and disguised by Jesus' human (and Jewish) appearance. It was the Jewish poet Franz Werfel who felt very close to Christianity and knew by heart that the Christian Nay of the Jewish Messiah by turning him to God had to be objected by a Jewish Nay to the Christian turnover of Jesus. This was the very essence of the confrontation between Gamaliel, the High Priest, and Paul in his play Paul among the Jews:

GAMALIEL rises Shaul! ... You are in the Temple ... We are wearing burial gown ... Thanks to the reconciliation that I will establish on the Day of Atonement! Hushed and firm What did the love of your Jesus change? Nothing has changed, as his anger had nothing changed, too. He turned over the changer's desks, but next day there were at their place again. It is not him and not me who can ban the evil, only the Torah, the Arcanum we serve to live, the holy binding of men!

PAUL The binding is rotten! Like an empty skin the word lies on the road!

GAMALIEL painfully retaining his composure This was not said by the man Jesus!

PAUL You talk about a man, Rabbanu? Oh, the world sinks in front of me, Jews and pagans! And only you are here, you and him. I myself want to be banned from him away, if you, Israel's hero, recognize him now, right now. A man!? Has a man ever mastered death and decay!? Has ever as man risen bodily from death!? And the light talking to me in front of Damascus, was it a man!? Has a man redeemed me from myself!? Is a man capable of giving God's ever renewing grace!? No, Rabbenu! This was no a man! He pulled on mankind like a garment, just as you and I wear burial gown. He himself,

${ }^{16}$ Klauck Hans-Josef, Judas - ein Jünger des Herrn, Freiburg-Basel-Wien 1987 (= QD 111).

17 Werfel, Franz: Theologumena, in: Ders., "Leben heißt, sich mitteilen". Betrachtungen, Reden, Aphorismen, Frankfurt/Main 1992, 185-291, bes. $237 \mathrm{f}$. 
the Messiah, the Shekinah that has become bodily, God's son who was before the world!

GAMALIEL approaching Paul and breathing heavily Shaul! For your sake and for mine: He was a man!

PAUL How could I! Man cannot do satisfaction for himself!

GAMALIEL It is only man who can do it. Tell me for the sake of the Temple: He was a man!

PAUL It was not in the Temple that the blood of the expiatory sacrifice was donated, but it was on the cross. Now the whole world is the Temple and its sacrifice. ${ }^{18}$

What Werfel wrote here and elsewhere in his oeuvre, was never meant to leave behind the "sphere of Judaism still cramped" and looking for a kind of universal view, as Stephanie Leuenberger suggested ${ }^{19}$, but to show the strict difference between Gamaliel, Werfel's Jewish hero in this play ${ }^{20}$, and Paul and his belief in the Messiah that Werfel did not really get hold of. It is true that Paul was one of the main representatives of early Jewish-Christian believers in Jesus Christ; but it is not true that Paul ever thought of Jesus being essentially equal with God, because Paul was a Jew and Jewish tradition has never been deifying anything or anyone born. Hence, the difference between Gamaliel and Paul could only have been in respect of Jesus, of his disputed Messiahship, and of the consequences concerning the Torah, the reconciliation, and the perception of the Messiah. Werfel dramatized the Jewish Nay to the Messiah Jesus; by overlaying the character of the Messiah with later dogmatic that was definitely out of reach to Paul; Werfel projected the Church's later teaching back to the confrontation between Gamaliel and Paul. But in this way Werfel opened a scene showing the justified Nay of Jewish tradition in respect of the God-man Jesus, which was a dogmatic topic that in itself implied the Christian Nay to Jesus as Messiah. But the Jewish Nay is twofold: It is against the claim that Jesus was the (Davidic) Messiah, and it is against the Christian claim (that Werfel referred to Paul) that Jesus was God. The Christian Nay got rid of Jesus as Messiah, too, and seems to be equal or at least similar to the Jewish Nay in respect of Jesus' being the Messiah. But the Christian Nay is founded is quite different because it identified the Messiah as God himself and sublimated his Messiahship disputable anyway.

Messiahs have come and gone in Jewish history; it was nothing else but time revealing or refuting them. ${ }^{21}$ That was what Paul felt, too. Time will prove if Jesus was the Messiah or not, and Paul hoped by heart that Jesus was the Messiah. But it is something totally different to develop the idea of a God-man and his divine efficacy obscuring the idea of the Messiah as time goes by. That is what pagan Christianity did - a concept as unprovable as the Davidic-Messianic concept of Jesus. Thus, Werfel's Gamaliel representing Judaism negated Jesus' being Messiah as well as pagan Christianity after Paul did, but it resisted to turn its Nay into something more impressive, more sublime, something divine as the pagan Christians strongly opted for from the $2^{\text {nd }}$ cent.

The late representatives of the God-man didn't have an easy job to do, not because they got lost in mysticism, but because the ongoing time did anything to oppose this idea, and they have been opposing it in powerful and tremendous ways. This stood against Christian rhetoric of fulfillment. But since this rhetoric was compelled to assert itself - because it affirmed fulfillment that could not be revoked -, and since it was

\footnotetext{
${ }_{18}$ Werfel Franz, Paulus unter den Juden, in: Ders., Dramen. Erster Band. Frankfurt/Main: Fischer Verlag 1959, 528 f; translation W.T.

${ }^{19}$ Leuenberger Stefanie, Schrift-Raum Jerusalem. Identitätsdiskurse im Werk deutsch-jüdischer Autoren, Köln-Weimar-Wien: Böhlau 2007, 157.

${ }^{20}$ Treitler Wolfgang, Über die Verzweiflung hinaus. Das Jahrhundert zwischen Stefan Zweig und Aharon Appelfeld, Göttingen: Vienna University Press 2015, 104.

${ }^{21}$ Boteach Shmuley, Kosher Jesus, Jerusalem: Gefen Publishing House 2012, 181.
} 
enriched by anti-Judaic attitudes and codes in its long run and simultaneously de-Judaized Jesus, almost 2000 years later hardly anyone on both sides, the Jewish and the Christian side, argued that Jesus was the connecting link between Judaism and Christianity; Jesus had become the opposite of Judaism represented by people heading to convert Jews in order to extinguish Judaism in the end, just in the way their Jesus was stripped of his Jewishness.

All of a sudden it were these people who were disturbed by the fact that after the abyss of the Shoa in Europe a Jewish State became real all of a sudden, and it were exactly those Jews fighting for it and defending it of whom Christian and Muslim teachers and preachers had intoned a requiem. ${ }^{22}$ Yoram Kaniuk, a Jew beyond devoutness and without being determined to defend Israel at all costs, wrote in his last novel 1948 he was working on when he was fatally ill about a meeting with a Christian monk, who had internalized both, an obsessive conviction of rhetoric of fulfillment and of the unbridgeable gap between Christianity and Judaism caused by the Christian teaching of the God-man:

At that time I was to get in touch with the Haganah headquarter in Jerusalem, which was under the command of David Shaltiel. On my way a thick monk blocked my way at the monastery Notre Dame. He smiled at me with a face covered by Christian mercifulness and said: You speak a good Hebrew, you fight a lost war, only Jesus will reign over Jerusalem, and then he gave me a book with the title Light and Felicity so that I may see the light (...) He said a young Jewish soldier happened to take part in a Christian ritual and found God. He saw the light, and he cried and asked to be admitted to the church. He was baptized here in Notre Dame and received the communion, and next day he was killed in action, not in the war of the church, but in yours. He was found not far from the Mount of Olives with Jesus on his lips and the cross in his hand, and when the story was told to his relatives, they took the cross and became Christians. I smiled about that nice, thick, lonesome man trying to alienate people from their faith on their road to hell. (...) The man asked: It's surely hard to fight, isn't it? All of a sudden he realized where I came from. I told him, some days ago I saw the head of one of ours on a pole, and indeed it is not easy to fight against a thing like that. God does not show up in any area, neither in yours nor in ours. (...) Grenades hit the ground close to us, shots banged, a woman yelled or cried, and the monk obviously felt sad because of his God and said, and yet, it is the same God, and I replied that our God cannot beget a son. He looked sad at me, maybe even merciful, because that was what Jesus wanted of him, and then all of a sudden he got red, the poor man almost screeched, who got caught in the land of war and hatred, and said Jesus had talked to the lame and the frail ones, to the outcasts who were banned by sanctimonious Jews from entering the Temple, and that was his very strength. - I left him and walked to the head quarter. ${ }^{23}$

Extinction of Jews by conversion to a fulfillment anything but real on the road to hell paved by thousands of dead - such an attempt extends the fiction of an anti-Jewish Christ to present days and never leads to human reason, as Yoram Kaniuk has recounted it in his straight and succinct stile, but to an exasperated and infantile emotion crying for help because of the break-down of the ramshackle Christian building of faith. That is why the monk did not realize that he was thinking and believing exactly in the same way of Christian traditions that led, as Imre Kertész worte, to "Auschwitz as a final outcome". ${ }^{24}$ Auschwitz - it is the anti-messianic, diabolic abyss into which each and every Christian tradition of the Messiah and even of the (omni-)potent God-man has engulfed. It was Friedrich-Wilhelm Marquardt who was one of the few German speaking theologians who has realized this theological collapse and tried to handle it. ${ }^{25} \mathrm{He}$ remained an outsider, obviously because the

\footnotetext{
${ }^{22}$ Barnavi Eli, Universalgeschichte der Juden. Von den Ursprüngen bis zur Gegenwart. Ein historischer Atlas, München: Deutscher Taschenbuch Verlag 2004, 281.

${ }^{23}$ Kaniuk Yoram, 1948. Roman, Berlin: Aufbau Verlag 2013, 142-144; translation W. T.

${ }^{24}$ Kertész Imre, Ich - ein anderer. Roman. Aus dem Ungarischen von Ilma Rakusa, Berlin: Rowohlt Taschenbuch Verlag 2002, 55.

${ }_{25}$ Marquardt Friedrich-Wilhelm, Von Elend und Heimsuchung der Theologie, München: Gütersloher Verlagshaus 1988, 139.
} 
teaching tradition of Christianity of all confessions and its theologically reflections have been considered more valuable and important that reflecting on the partly fatal effects it has been having on the people of Israel to which Jesus belonged. These effects were and are caused by fundamental breaks that happened within the first two hundred and fifty years of Christian development.

Auschwitz is a strict No! against such a teaching. The $614^{\text {th }}$ commandment Emil Fackenheim has formulated means that forever the voice of Auschwitz forbids even the slightest approach to the extinction of the Jewish people, of Judaism, and of its tradition. Therefore, "I cannot be obliged to do what I no longer can do!" (Fackenheim, 1994, p. 300). This statement binds theological and Christological doctrines as well. Anyway, they developed probabilities fading away face to face with God as the eternal mystery. And their probabilities driven as high as possible for human ratio did not become real; neither redemption nor liberation or reconciliation, neither Israel's integrity nor the Kingdom of God at the messianic end of time had turned real, but most of a kind of their rear panel, threat against those who did not follow these doctrines; and it was not only threat, but also frequent persecution including destruction of whole Jewish communities. Jews were frequently exposed to Christian designation of not belonging to the society; a Christological thought that turned Christology of heathen-Christian teaching and its basic anti-Jewish attitude into effective, anti-Jewish political reality.

These facts altered the Jewish environment in the same way as they were the very presuppositions to perceive the man from Nazarene as a trans- and eventually anti-Jewish character. Ostracism was established through demarcation, in respect of time by historicizing Judaism and ignoring its vital presence, and in respect of places by frequently executing the expulsion of Jews as a religious-political program and by forcing the Jewish population that remained into ghettos where they led their poor and meager lives that could be controlled easily. ${ }^{26}$ The end of this trend was clear: Jews were no longer considered men, but objects reified by religious hatred that remained real and effective even under modern political conditions. Unprejudiced people do not understand why this hatred could start and move on through the ages, at least children. Aharon Appelfeld wrote about that in his novel Adam and Thomas:

'I have the feeling that since the ghetto, nothing makes sense. They send away the old people. Why are they sending away the old people? Why are they sending away children? What harm did the children do? What harm did the old people do?' Thomas spoke emotionally.

'They are Jews', Adam answered quietly.

'Because they're Jews, they have to be sent away?'

'You know, Thomas. People don't like Jews.'

'I can't figure that out. Apparently I have to experience and learn more,' said Thomas, and then he stopped talking. ${ }^{27}$

Is it possible to get rid of hatred against Jews through learning?

Or through experience?

\footnotetext{
${ }^{26}$ Kober Adolf, Art. Judenviertel, in: Jüdisches Lexikon. Ein enzyklopädisches Handbuch des jüdischen Wissens in vier Bänden. Begründet von Dr. Georg Herlitz und Dr. Bruno Kirchners. Mit über 2000 Illustrationen, Beilagen, Karten und Tabellen. Band III, Frankfurt/Main: Athenäum Verlag ${ }^{2}$ 1987, 457-460; Brenner Michael, Kleine jüdische Geschichte, München: Verlag C. H. Beck $2008,134 \mathrm{f}$.

27 Appelfeld Aharon, Adam \& Thomas. Translated from the Hebrew by Geffrey M. Green. Illustrations by Philippe Dumas, New York - Oakland: Seven Stories Press 2015, 42.
} 
The roots of anti-Semitism are deep and thousands of years old. ${ }^{28}$ It has spread in languages as well as in different ways of thinking, in everyday life as well as in unconscious emotions, in areas where Jews used to live or still live, as well as in regions in which not a single Jews has shown up. Almost each thing and a hundreds of millions of people have been contaminated by an anti-Jewish atmosphere, a fact easily proven by studies on anti-Semitism. $^{29}$

And yet - even if it may seem absurd to stand up against it, it is and will remain a kind of commandment to me as a Catholic theologian not just to show ways out of it, but to draft it face to face with those developments, and that includes their critique in order to perceive why they have become so dreadful and even fatal for the Jewish communities as well as for the Jew from Nazareth being "stolen from our community, stripped of his Jewishness, and in large measure made into an enemy of his people" ${ }^{\text {, }}$, as Shmuley Boteach wrote it.

I do not pretend to show the real and authentic profile of the Messiah of Nazareth. That is something totally impossible. 2000 years of cryptic history have covered and sealed him, hardly anything can be made accessible to him. My motivation is not to add another fiction to Christology; what really drives me are the "eyes of the eternal brother" 31 and his memory lost within Christianity by a kind of theological amnesia and many compromises that Christianity developed because of the woes of the non-Messianic time that kept going on. It were obviously these woes through which the commitment of Jesus as the Davidic Messiah soon faded away and got lost, eventually.

\section{Traces of the Messiah in Messianic Judaism of the 1st Century}

Within the early writings of the New Testament written exclusively by Jews one can find messianic ideas attributed to the man of Galilee. They did not come out of nothing, but picked up motifs of Israel's prophecy and connected them to John Baptist and to Jesus and stressed them in a messianic way (Vermes, 2012, p. 31). This fit to Jesus's profile being sharpened and deepened by the religious and political circumstances at that time that was full of apocalyptic notions and expectations ${ }^{32}$, most of all of a struggle between good and evil that brought to life again apocalyptic visions of the Book of Daniel (Freyne, 2014, p. 151). It was this very book that did not only fuel the ideas of the young group of followers of the Jesus movement, but also other Jewish groups looking and hoping for final redemption; at least at the beginning of the Jewish-Roman war in $66 \mathrm{C}$. E. were these expectations part of the conviction of rebellious groups and then later again during the Bar-Kochba revolt in the years 132-135 C. E.

So these messianic ideas were widespread, but also widely opposed and always came to an end sooner or later because of their deep ambiguity. They broke down either because of defeat like the Zealots or the Bar-Kochba movement or because of the fact that the Messiah did not turn history for the better, but instead

\footnotetext{
${ }^{28}$ Nirenberg David, Anti-Judaismus. Eine andere Geschichte des westlichen Denkens, München: C. H. Beck 2015.

29 Robert S Wistrich was one oft he most prominent researches in this field: Roberts Sam, Robert S. Wistrich, Scholar of Anti-Semitism, Dies at 70 : http://www.nytimes.com/2015/05/28/world/europe/robert-s-wistrich-scholar-of-anti-semitism-dies-at-70.html?_r=0 (Abfrage 23.10.2015); Sokol Sam, Robert Wistrich, leading scholar of anti-Semitism, dies of heart attack: http://www.jpost.com/Diaspora/Robert-Wistrich-leading-scholar-of-anti-Semitism-dies-of-heart-attack-403590 (Oct. 23rd, 2015).

30 Boteach Shmuley, Kosher Jesus, Jerusalem-New York: Gefen 2012, 197.

31 This is the title of a short and quite unknown novel of Stefan Zweig written in 1922 telling an Indian story about someone who committed a murder against his brother without knowing.

${ }^{32}$ Harrington David J., Matthew's Cheristian-Jewish Community, in: Rudolph David / Willits Joel (Hg.), Introduction to the Messianic Judaism. Its Ecclesial Context and biblical Foundation, Zondervan: Grand Rapids 2013, 159-167, bes. 161.
} 
violence kept the reigns and the Jesus movement turned into a movement lead by of writers. The mere fact that writing arose was a contradiction to a real messianic faith, as was the coinage of the Bar-Kochba movement ${ }^{33}$ a hundred years later intending not the messianic end of times but a new political system. If Jesus were the Messiah, as parts of the early Christian writing suggested, no one ever could have had time enough to start thinking and writing about him simply because time would have ended. That is the very reason why Jesus himself did not write anything for times to come and did not leave a testament behind. ${ }^{34}$ No Davidic Messiah would have anything left to settle for the time to come, because there would be no time to come. For a real Davidic Messiah it is as simple as that.

\section{A. Paul Appears and Writes}

This was the problem of this new community believing in the Messiah and being part exclusively of the Jewish community; most of their members were at home in Jerusalem (Freyne, 2014, p. 202) in an atmosphere that had nothing to do with the strange reading and distortive comprehension the Hebrew bible by "total outsiders". ${ }^{35}$ And yet, in order to keep the faith in Jesus as the Messiah, that fact that the end of time proclaimed either by Jesus or the disciples closest to him or by both hat not yet occurred forced these Jewish communities to reach out to a new interpretation. But the new interpretation that was soon to be developed was anything but biblical ${ }^{36}$ and differed very much from the idea of the Davidic Messiah which was part of biblical tradition: the idea of the second coming of the Messiah who was already on earth. This idea was based on the commitment of Christ's resurrection and affirmed Jerusalem as the center of this messianic community, as Seán Freyne pointed out referring to the group around Jacob: "Once they were assured that Jesus was indeed the Messiah of Israel, but a very different Messiah from what they have previously anticipated, and that his life could be presented as the inauguration of the messianic age, a presence in Jerusalem was both expected and demanded" (Freyne, 2014, p. 201).

It was this idea that gave way to thinking of time as being extended, and in the same way it was exactly this idea through which these communities slowly, but surely lost their Davidic Messiah as well as the importance of Jerusalem as center of the messianic confraternity. Paul did not only know that, but he implemented it in his own days. Jerusalem was important to him still, but its importance faded away as well as the convent of the Torah that has been observed quite naturally by the messianic Jews in Jerusalem. As Paul developed the extension of time and brought it forward, he became the most decisive protagonist who on the

\footnotetext{
${ }^{33}$ Barnavi Elie, Universalgeschichte der Juden. Von den Ursprüngen bis zur Gegenwart. Ein historischer Atlas, München: Deutscher Taschenbuch Verlag 2004, 61.

34 There is just one hint in the Gospel tradition that Jesus wrote something. John 8:3-8 has it: "And the scribes and Pharisees brought unto him a woman taken in adultery; and when they had set her in the midst, they say unto him, Master, this woman was taken in adultery, in the very act. Now Moses in the law commanded us, that such should be stoned: but what sayest thou? This they said, tempting him, that they might have to accuse him. But Jesus stooped down, and with his finger wrote on the ground, as though he heard them not. So when they continued asking him, he lifted up himself, and said unto them, he that is without sin among you, let him first cast a stone at her. And again he stooped down, and wrote on the ground". What did Jesus write? Maybe it was just two words fitting to this scene: לא תרצח - Lo tirzeach! - Thou shalt not kill (Ex 20:13). Since these words (whatever they might have been) were written on the ground they were not meant to be his testament for a long run, but just a distinct remembrance of a basic commandment of the Tora. This hint also proves that Jesus knew to read and to write. So if we don't have any line of Jesus' writing, this fact has to do with his being (proclaimed) Messiah. God's man of the very last period of time did not write anything as his authentic legacy, because it was simply superfluous, even contradictory.

${ }^{35}$ Fredriksen Paula, The Birth of Christianity, in: Fredriksen Paula / Reinhartz Adele (Hg.), Jesus, Judaism, and Christian Anti-Judaism. Reading the New Testament after the Holocaust, Louisville-London: Westminster John Knox Press 2002, 8-30, hier 28.

${ }^{36}$ Boteach Shmuley, Kosher Jesus, Jerusalem-New York 2012, 181.
} 
one hand prohibited the dissolution of this messianic community within Judaism, but on the other hand he promoted its dissolution as an effect of his writing and through his writing. He did that in two ways connected to each other:

First, Paul himself had to believe strongly, even in a manic way, in the second coming of the Messiah. ${ }^{37}$ Without it his whole message would have been in vain. In this way he got out of the dilemma that the Messiah was supposed to end the time; for Paul he had only did not yet come again at the real end of time.

Secondly, Paul needed strong border lines against Judaism in order to keep this idea, because aside from the very small messianic community in Jerusalem Jews did not recognize Jesus as Messiah, neither now nor in the near future. Paul drew these border lines by reading and interpreting the Hebrew Bible, and he drew them not just in polemic ways, but even by partly conscious and destroying demotion of central issues of Jewish tradition and Jewish faith, even of it very basis, the Torah. Paul's demotion of the Torah did not just work to suspend its commandments for pagans, as Christian theology usually has been stating (Wilson, 2013, p. 236) its aim was its complete suspension because of the Messiah, an idea not totally unthinkable within Judaism ${ }^{38}$, and included the destruction of Judaism as far as it did not believe in Jesus as Christ (Klinghoffer, 2005, p. 106) (this could correspond at its outmost fringe with the Messianic idea as it was executed by the wrong Messiah Sabbatai $\mathrm{Zevi}^{39}$ ). Gershom Scholem wrote that Paul's messianic faith had a specifically biographical background that was rationalized afterwards and became his Messianic conviction: It was Paul's vision of Christ in front of Damascus (Act 9:3; 1Cor 9:1). ${ }^{40}$ This rationalization fits to the integration of the irrational that every religion has been carrying out in order to domesticate the irrational past of its own and to make it practicable.

Paul's fundamental demotion of the Torah in Rom 3 did not contradict his parable of the olive tree of Rom 11:17-31, but was its presupposition. Aside from his hardly reasonable, but traditional statement in which Paul tried to reveal the "mystery" of "a partial hardening" (Rom 11:25) of Israel, he pointed out that Israel's redemption and salvation would be real only through Christ and in no other way. Judaism keeping its anti-messianic hardening because of its refusal to give up the Torah and to give in to Christ would perish for sure when Christ would return. Thinking of that kind easily reveals what the historian David Nirenberg called the "dreadful pedagogics" ${ }^{41}$ of Paul, which found its core in Paul's view of history which clearly propagated the end of studying Torah because of the Messiah who already was there and introduced the last and very short period of history. ${ }^{42}$ Within this last time span Jews who did not recognize Jesus as Messiah were considered to be castaway belonging to the old world where the "peculiar enemies of God"43 lived. This view was not altered by Paul's highest commitment when he wrote that "I could wish that I myself were accursed and cut off from Christ for the sake of my brothers, my kinsmen according to the flesh". (Rom 9:3). Paul obviously thought of a perilous drama revealing his Messianic fever. In respect of God, such a thought is capable of darkening the

\footnotetext{
37 Vermes Geza, Christian Beginnings. From Nazareth to Nicaea, New Haven-London 2012, 81 und 105.

38 Scholem Gershom, 137. Die Theologie des Sabbatianismus im Lichte Abraham Cardosos, in: Ders., Judaica I, Fraunkfurt/Main: Suhrkamp Verlag 1963, 119-146, bes. 137.

39 Scholem Gershom, Die Krise der Tradition im jüdischen Messianisums, in: Ders., Judaica 3. Studien zur jüdischen Mystik, Frankfurt/Main: Suhrkamp Verlag 1973, 152-197, bes. 170-176.

40 Scholem Gershom, Die Krise der Tradition im jüdischen Messianisums, in: Ders., Judaica 3. Studien zur jüdischen Mystik, Frankfurt/Main: Suhrkamp Verlag 1973, 152-197, bes. $165 \mathrm{f}$.

${ }^{41}$ Nirenberg David, Antijudaismus. Eine andere Geschichte des westlichen Denkens, München: Verlag C. H. Beck $2015,72$.

42 Ben-Chorin Schalom, Paulus. Der Völkerapostel in jüdischer Sicht, Gütersloh: Gütersloher Verlagshaus 2006, 48 f.

43 Nirenberg David, Antijudaismus. Eine andere Geschichte des westlichen Denkens, München: Verlag C. H. Beck $2015,74$.
} 
mystery of Israel's God and turning it into something dreadful. And in respect of non-messianic Jews, they speak out a kind of definite verdict on them fitting exactly to the Paul's commitment to be cut off from Christ as from the final redemption.

Paul appeared as a significant figure in the early days of the messianic Jewish community and started writing. By writing he was filling in a gap between the resurrected Christ and his second appearing at the end of time. ${ }^{44}$ Paul did not fill in this gap because he wanted to produce writings for a long run or even to have them canonized in later days as (part of the) Holy Scripture. He wrote within a specific messianic horizon and constellation. Since for Paul the end of time has come near and was even almost at hand, he felt himself forced to convert as many people as possible to his messianic idea - a plan typical for all groups which expected the end of time and tried to prepare as many non-believers as possible by turning them towards a specific faith. ${ }^{45}$ His letters worked exactly in the same way: They were tense epistles of a short run importance because of the Messiah who was so near, and therefore they were fired by an immense missionary blaze. His letters are messianic products created by Paul's propagated idea that the Messiah has yet been in earth and that he is to come in the nearest future.

Who the Messiah Jesus was to Paul, is very clear. He was born as descendant of David "according to the flesh" and therefore Messiah, as Paul wrote in an odd dualistic setting ${ }^{46}$ in Rom 1:3. The introduction of his letter to the Romans contained the historically first ascription of the Davidic messiahship to Jesus ${ }^{47}$ we have come to know of within the corpus of the New Testament. It was Paul who favored this very ascription, and it is important to realize that, because again the fact must be considered that Paul himself was no eye or ear witness of Jesus, but he was turned into the witness of the Messiah by an event that he had kept indistinct in respect of the region, while later on Luke identified it as an event close to Damascus. ${ }^{48}$

There is a considerable consent that in no tradition we know by now Jesus did ever designate himself as Messiah, but this designation was always spoken out by others (Bockmuehl, 2013, p. 266). This cannot be considered a deletion of later authors who bashfully put aside Jesus' self-designation, but it is according to the historical conditions. If Jesus ever had declared himself Messiah, especially Davidic Messiah, he would have challenged the fragile religious and political arrangement between the Roman occupants and the rulers of Judah appointed by the Romans. Herod Antipas, in those days tetrarch of Perea and Galilee ${ }^{49}$, where Jesus and the

\footnotetext{
${ }^{44}$ Gager John G., Paul, the Apostle of Judaism, in: Fredriksen Paula / Reinhartz Adele (Hg.), Jesus, Judaism, and Christian Anti-Judaism. Reading the New Testament after the Holocaust, Louisville-London: Westminster John Knox Press 2002, 56-76, hier 61; Fredriksen Paula, Jesus of Nazareth, King of Jews. A Jewish Life and the Emergence of Christianity, New York: Vintage Books 2000, 246.

${ }^{45}$ Gager John G., Paul, the Apostle of Judaism, in: Fredriksen Paula / Reinhartz Adele (Hg.), Jesus, Judaism, and Christian Anti-Judaism. Reading the New Testament after the Holocaust, Louisville-London: Westminster John Knox Press 2002, 56-76, bes. 60 .

${ }^{46}$ Nirenberg David, Antijudaismus. Eine andere Geschichte des westlichen Denkens, München: Verlag C. H. Beck 2015, 67-71.

${ }^{47}$ Bockmuehl Markus, The Son of David and the Gospel, in: Rudolph David / Willits Joel (Hg.), Introduction to the Messianic Judaism. Its Ecclesial Context and biblical Foundation, Zondervan: Grand Rapids 2013, 264-272, bes. 262. This does not mean that this ascription was not known before, nor that Paul developed it about ten years after his first writings. Moreover it means that the Romans Paul turned to had some idea of a Davidic Messiah, probably because a considerable number of the Roman community consisted of Jews who became believers in Jesus as Christ, while neither the Corinthians no the community in Thessalonica or in other place of Asia Minor had many of them within their circles. And that might also be the reason why Paul was dealing with the Gospel and the Torah in a systematic way in no other letter as in his letter to the Roman community.

${ }^{48}$ Nirenberg David, Antijudaismus. Eine andere Geschichte des westlichen Denkens, München: Verlag C. H. Beck $2015,62$.

49 Simchowitsch Jakob Naphtali, Art. Antipas, in: Jüdisches Lexikon. Ein enzyklopädisches Handbuch des jüdischen Wissens in vier Bänden. Begründet von Dr. Georg Herlitz und Dr. Bruno Kirchners. Mit über 2000 Illustrationen, Beilagen, Karten und Tabellen. Band I, Frankfurt/Main: Athenäum Verlag 1987, 331.
} 
core of his disciples stemmed from, would have brought an immediate end to such a challenging claim; already John the Baptiste who preached fairly below such a claim, but still attracted the crowd "for they were very greatly moved [or pleased] by hearing his words", was brought to put to death by Herod, "to prevent any mischief he might cause, and not bring himself into difficulties, by sparing a man who might make him repent of it when it would be too late". ${ }^{0}$ (Josephus Flavius). It is for sure that Herod would have proceeded in the same way with a (self-)proclaimed Davidic Messiah - especially with a Messiah coming from the former Hasmonian stronghold, from Galilee, where the family of Herod was despised (Fredriksen, 2000, p. 248). Herod might have even acted faster, for he knew well that the people had never respected Herod's the Great family and his offsprings as a true and legitimate sovereigns. Having been part of the Idumeans who have been converted to Judaism by force, they did not weigh much; and, besides this, they have arrogated to occupy and keep King David's throne. ${ }^{51}$ So if Jesus ever had proclaimed himself the Davidic Messiah, he definitely would have been detained and executed by Herod long before he could have even thought of going beyond Galilee and causing problems in Jerusalem.

That is what one has to bear in mind concerning Paul's ascription of Jesus as Davidic Messiah in Rom 1:3. It has been possible by Paul's biographical distance from Jesus as well as by his resolute and intellectual formation of the figure of Christ and by his pharisaic education through which Paul was superior to the folks around Jesus. ${ }^{52}$ By his teaching, by his traveling, and by his writing Paul developed Jesus as Davidic Messiah for the new and arising communities which turned step by step away from pagan or partly Jewish commitments to communities which displayed a more and more pagan-Christian kind of imprint. The fact that this messianic idea became the fundament of the gospels (Harink, 2013, p. 273) written after Paul has a lot to do with Paul himself. Whether Jesus was actually proclaimed Messiah by his followers (Fredriksen, 2000, p. 257) and whether Paul just referred to those commitments, is historically unclear because the gospels themselves dealt, as we will see later, very much with the question of Jesus as Messiah since it became noticeably clearer as time went by that this commitment turned into discrepancy with reality still going on as ever in a widely anti-messianic manner.

This messianic introduction in Rom 1:3 is followed by a long exposition of the inclusion of the pagans within the messianic promises and their history ${ }^{53}$ that could be considered to correspond to a Davidic-messianic concept at its very beginning. What was up was to enforce the messianic expectation by truly anticipating it and make them become real. Paul's messianic faith and its enforcement included the pagans. Even they were meant to believe in the Messiah Jesus, and their belief was a decisive step on the path of pacification and preparation of the Kingdom of God that had come so near (Fredriksen, 2000, p. 95). Paul absolutely expected - according to his parable of the olive tree - that the pagans' belief in the Messiah would cause the non-messianic Jews also to believe in him, when they would see the clearly messianic sign of peace that would arise and of Israel's liberation from all his enemies who turned into companions. By that time the Messiah would return in order to establish universal fulfillment Paul desired so much in his letter to the

\footnotetext{
${ }^{50}$ AJ XVIII 5,2 (zit. nach der folgenden Ausgabe: Flavius Josephus, Jüdische Altertümer. Übersetzt und mit einer Einleitung und Anmerkungen versehen von Dr. Heinrich Clementz. Mit Paragraphenzählung nach Flavii Josephi Opera recognovit Benedictus Niese (Editio minor), Berlin 1888-1895, Wiesbaden: marixverlag 2006, 886; Übersetzung nach).

${ }_{51}$ Schalit Abraham, König Herodes. Der Mann und sein Werk, Berlin-New York: Walter de Gruyter 2001, 21 und 41.

52 Ben-Chorin Schalom, Paulus. Der Völkerapostel in jüdischer Sicht, Gütersloh: Gütersloher Verlagshaus 2006, 63.

${ }^{53}$ Gager John G., Paul, the Apostle of Judaism, in: Fredriksen Paula / Reinhartz Adele (Hg.), Jesus, Judaism, and Christian Anti-Judaism. Reading the New Testament after the Holocaust, Louisville-London: Westminster John Knox Press 2002, 56-76, hier 72 .
} 
Romans (Vermes, 2012, p. 79).

It is exactly here where one will meet the chronic problem of Jesus as Davidic Messiah. The idea of his second coming became and remained a conflicting loophole out of the experience of ongoing time face to face with Jesus as messiah. Neither Paul nor the tradition following him freely chose this conflicting connection; it was forced on them, because they did not and maybe even could not get rid of their messianic faith, but kept it against their experience of ongoing time that turned into a kind of double negativity: Time did not only not turn into the better, but no moment ever did reveal or at least indicate the return of the Messiah. The importance of the title of the Messiah to Paul ${ }^{54}$ that he established by burning rhetoric did not correspond to the time being. And the justification of Jesus as Messiah by inventing his second coming did not solve the problem Paul had, but deflected it to the future (Fredriksen, 2000, p. 264) and preserved it. The solution could have happened only in that way that Paul's writing was not ended by his death, but by the second coming of Paul's messiah. At one go Paul would have been right, his writing would have lost all its necessity, and everything and every time would have been resolved and saved by God's Kingdom.

The fact that Paul had to write anyway and to enforce the second coming of Christ was a consequence of Christ being killed on the cross without any messianic sing or any messianic resistance. Christ being killed that way had a shocking impact in his followers that they had to deal with (Fredriksen, 2000, p. 97); Paul who had no immediate experience of this shock but only heard and learnt about it afterwards, was the first who tried to get beyond it right at the beginning of his writing (Fredriksen, 2000, p. 79), and that did not happen just by chance. For him it was far easier to get along with the scandal of Jesus' crucifixion because he did not witness it, but the glorious Lord he envisioned ever since his conversion. Therefore, Jesus' resurrection did not bear immediate messianic signs (Fredriksen, 2000, p. 126) (as for Matthew some decades later), but it was just the start of an eschatological expectation beyond Messianic faith (1 Cor 15) and left history untouched.

Paul died without the second coming of Christ. Fe did not see him fulfilling God's promises to David. While Paul got rid of his messianic problem through his death, it remained his disputed heritage for the following generations, an heritage whose problems deepened with every day passing by in the same way as the days before had been, days in the shade of Roman power and its violence proving day by day who the real soter was. It was not the Messiah of David's house, but since Jesus' days it was Augustus, the Roman imperator. And he was only concerned with his own interests and agendas and not impressed by messianic ideas even if they reached Rome, for these ideas did not fit to a real Empire and its firmness, but to a weak and barbaric people living from one doom to another.

In the face of these circumstances, Paul's writing led the pagan Christians into a kind of no-man's-land, a kind of "Nothingville, ... where nothing's real" something real and reasonable - referring to ideas that were not and could not have been part of the Jewish tradition. Paula Fredriksen accurately wrote about:

Paul walked these Gentile-in-Christ into a social and religious no-man's-land. In the time before the Parousia, they literally had no place to be. And in the long run, their position would prove untenable: It is precisely this Gentile group who fall victim to anti-Christian persecutions in the long centuries until the conversion, in 312, of Constantine. But Paul, again, did not expect a long run. (Fredriksen, 2000, p. 135)

\footnotetext{
${ }^{54}$ Bockmuehl Markus, The Son of David and the Gospel, in: Rudolph David / Willits Joel (Hg.), Introduction to the Messianic Judaism. Its Ecclesial Context and biblical Foundation, Zondervan: Grand Rapids 2013, 264-272, bes. 269.

55 Part of the short song Nothingville Elvis Presley sang during his 68 comeback special (https://en.wikipedia.org/wiki/Elvis_\%281968_TV_program\%29).
} 
The no-man's-land turned out dangerous and anti-messianic. In fact, these gentiles lost their social relations by their commitment of Jesus as Christ, no social agreement protected them any longer. They turned into others, into people belonging nowhere and threatened by death every day. In the end, they were not saved by Christ's second coming, but by upheavals of the Roman Empire that happened some centuries later. But that took quite a long time and was accompanied by a lot of bloody and violent conflicts caused by different reasons. And even at the end of these conflicts has not come the man from Galilee again, but instead of his Christological basics of the official doctrine of the church had been erected. Its fundamental outlines as well as its content were taken from Greek and Roman philosophical traditions that at the same time deepened the aversion of the pagan Christians against Jews and Judaism, stabilized them by the claim of divine authority, and covered the Jewish roots that have already been fading. Nothing substantial remained of Paul's messianic traces; he obviously was not successful in turning the pagans' mind to the Davidic Messiah, as we will see later.

\section{B. A Messianic Jewish Community (Didache)}

While Paul turned to the gentiles, there still existed Jewish groups believing in Jesus as Messiah. But their texts haven never been acknowledged holy and canonical; they disappeared together with their Jewish communities and got lost eventually. A few were kept and hidden at unknown places. That is how remembrance has been extinguished by the gentile Christianity who put an end to Jewish-Christian communities through the church's official teaching since the $4^{\text {th }}$ cent.

But once and a while things happen by chance and bring back things one even could not remember because there were left. Something like that happened in the year 1873, when the Byzantine metropolitan Philotheos Bryennios discovered an unknown text in the library of the monastery of the Holy Sepulcher in Constantinople. ${ }^{56}$ This text turned out to be a copy of a document of an obviously Jewish community of the $1^{\text {st }}$ cent. C.E. that believed in Jesus as Messiah and was theologically and literally independent of the Pauline and the New Testament literature (Vermes, 2012, p. 146).

The independence of the text form the main lines of the later New Testament was the reason of its fate. Because of the victory of the Pauline-Johannean tradition that has been canonized by the gentile church at the end of the $4^{\text {th }}$ cent. $^{57}$ Jewish-messianic texts like this one that was discovered by chance disappeared into a cryptic sphere. Even references to the Didache by Church Fathers remained ambiguous ${ }^{58}$, since the orthodoxy of the Fathers was bound to a clearly anti-Judaic core which served as a seismographic sensorium of pagan-Christian groups to detect, to identifiy, and, as a consequence, to extinguish every kind of what they thought could (re-)judaize Christian communities. ${ }^{59}$ This attitude put the final nail in the coffin of the Didache, because it "certainly reflects a close familiarity with Jewish religious culture in terms of ethical demands of the two ways and Jewish fasting practices, washings, and prayers, especially in the context of meals, yet it seeks to draw clear lines between its own adherents and other Jews" (Freyne, 2014, p. 270) But drawing clear lines just meant that the community of the Didache exposed itself to a clear Messianic faith within Judaism and was caused by the messianic accent of Jewish ethics and conviction. That is why the later Christian communities dominated by former pagans identified the Didache - and maybe a considerable number of other

\footnotetext{
${ }^{56}$ The Didache. A Commentary by Kurt Niederwimmer. Translation by Linda M. Maloney. Edited by Harold W. Attridge, Minneapolis: Fortress Press 1998, 19; Tuillier André, Art. Didache 731-736, in: TRE 8, bes. 731.

57 DH 179-180.

58 The Didache. A Commentary by Kurt Niederwimmer. Translation by Linda M. Maloney. Edited by Harold W. Attridge, Minneapolis: Fortress Press 1998, 6-13.

59 Nirenberg David, Anti-Judaismus. Eine andere Geschichte des westlichen Denkens, München: C. H. Beck 2015, 118-143.
} 
messianic-Jewish writing - as an input of Judaism within Christianity; pagan Christianity was simply sure that such an input was anachronistic and should be forgotten, together with other Jewish specifics and writings. The fact that the Didache got lost and was found just at random is a significant comment on the whole affair.

Surly, the Didache is no theological tractate, "but a rule for ecclesiastical praxis, a handbook of church morals, ritual, and discipline". ${ }^{60}$ Anyway, it reveals a specific spirit that the gentile Christian did not cope with, since it was the spirit of a Jewish tradition. Geza Vermes (2012) called it an "eschatological spirit" (p. 145) out of which were written the apocalyptic scenes of the last chapter that goes about false prophets, the Anti-Christ, the loss of faith, and the threefold sealed finale when heaven will be expanded, the shofar will be blown, and the dead will be resurrected, when Jesus, the Lord, will come.

Jesus has never been called Son of God within the Didache. Only at the end there is a warring that someone will come and appear as Son of God accompanied by miracles and power. ${ }^{61}$ But this one is not Jesus, but the Anti-Christ. "And at that time the one who leads the world astray will appear as 'son of God' and will work signs and wonders, and the earth will be given into his hands, and he will do godless things which have never been done since the beginning of time" (Vermes, 2012, p. 146). The idea so popular in pagan Christianity and later as a dogmatic formula of the Son of God who was both man and at the same time God in essence, has been repudiated by the Didache as an act of apocalyptic deception and even more as the last and keenest kind of blasphemy. Not even a single title of Jesus within the Didache came close anything like this.

Jesus as known to the Jewish-Christian Didache is not the eschatological or apocalyptic Son of God, he is neither eternal Son of God nor God's Son in time. The Didache has been using only titles referring to Jesus which it took from Jewish traditions and which were understandable for Jews in a clearly monotheistic way. That is the very reason why the Didache also avoided attributing identical capacities and qualities to God and Jesus, something that again has become very popular in later days. ${ }^{62}$ The Didache used to speak only of Jesus as Lord, but never of the Eternal One (Vermes, 2012, p. 146). He is the Lord for the community of the Didache, while in relation to God Jesus is servant, in Hebrew eved. And as a servant he has nothing to do with anything like a sacrifice he may have offered God for the sake of men's redemption; it is striking that the Didache did not mention anything like a sacrifice Christ offered, because the Didache dealt a lot with rituals. Again one can see that the thought of Christ's sacrifice that became so popular within the pagan Christian communities later and had its focus on the Eucharist was not even foreshadowed by the Didache. Geza Vermes pointed that out clearly:

In short, the Jesus of the Didache is essentially the Servant of God, the great eschatological teacher who is expected to reappear soon to gather together and transfer the dispersed members of his church to the Kingdom of God. The ideas of atonement and redemption are nowhere visible in this earliest record for Jewish-Christian belief. Nor can one find any hint at the sacrificial character of Jesus' death and its Pauline symbolical re-enactment in the rituals of baptism and the Eucharist. Needless to say, the Johannine idea of the eternal and creative Logos is nowhere in the horizon either. (Vermes, 2012, p. 147)

The crucial point of the Didache, which is a document of community believing in Jesus as Messiah, is as fundamental for that kind of messianic Christianity as it has been misconceived or simply ignored: The very

${ }^{60}$ The Didache. A Commentary by Kurt Niederwimmer. Translation by Linda M. Maloney. Edited by Harold W. Attridge, Minneapolis: Fortress Press 1998, 2.

61 The Didache. A Commentary by Kurt Niederwimmer. Translation by Linda M. Maloney. Edited by Harold W. Attridge, Minneapolis: Fortress Press 1998, 219.

62 Müller Gerhard Ludwig, Art. Idiomenkommunikation, in: LThK 5, 403-406. 
messianic spirit of the Didache does not contain any hint of Christ's death as a sacrifice of redemption and certainly did not elaborate a theory of that kind. For the Messiah, as he has been confessed by this community, did not sacrifice anything or anyone, but he fulfilled God's promise of His coming Kingdom. The commitment to Jesus as Messiah and a theory of a sacrifice excluded each other. That is why the later composition of a theological theory of Jesus as a sacrifice is to be considered a clear and distinct sign of pagan-Christian developments that transferred the title of the Christ, i.e., of the Messiah, to something else without remaining linked to the messianic atmosphere of the Jewish Christ-believers. Christ as a sacrifice put an end to Jesus as a Jewish Messiah and even more top Jesus as a Jew.

That is what can be proven by the Eucharistic text of the Didache without effort. And by the way, it did not happen by chance that within this Eucharistic part of the Didache Jesus has been called explicitly Messiah ${ }^{63}$, but not a sacrifice offered to God who gave redemption to man through the Jesus being sacrificed, as it is stressed by the Eucharistic texts of today. The Didache praises God through his servant Jesus, and together with Jesus the community thanks God, together with the Messiah who belonged to the same tradition as the community of the Didache being Jewish, strictly monotheistic ${ }^{64}$, and legitimated by Davidic roots.

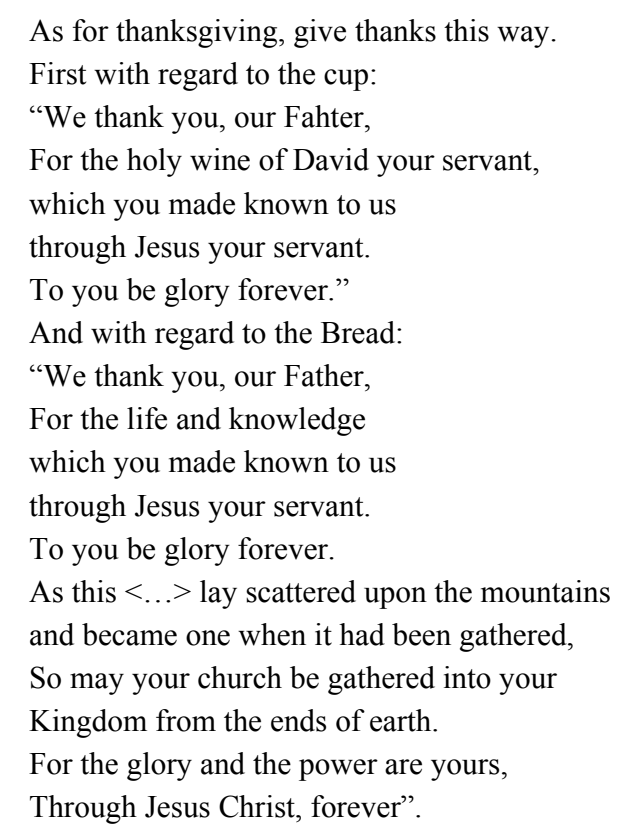

This prayer contained the hoping for the Davidic Messiah and the expectation of the end of time that has come close. This clearly indicates that the Didache is a very old, Jewish-Christian document. That is why it

\footnotetext{
${ }^{63}$ Vermes Geza, Christian beginnings. From Nazareth to Nicaea, New Haven-London: Yale University Press 2012, 146 ("the title 'Christ' is nowhere mentioned on its own, nor is the messiahship of Jesus stressed. This absence of the messianic ... is in harmony with the unwillingsness of the historical Jesus to accept the designation Christ/Messiah ... The combined title 'Jesus Christ' appears only once in the benediction formula, 'For the glory and the power are yours through Jesus Christ for ever' (Did. 9.4), where Christ may have been quasi-automatically appended to 'Jesus' in the course of the transmission of the Didache in antiquity. It must also be underlined that the Didache completely avoids the use of 'Son' or 'Son of God', as has been observed, is found only once, where it is the self-designation of the Antichrist, the "seducer of the world"' (Did. 16,4).

${ }^{64}$ Aquila H. I. Lee discussed in the introduction of his thesis From Messiah to Preexistent Son the Jewish commitment to monotheism and came to the point: "We therefore strongly uphold the view that the first century Jewish monotheism was not broken or compromised by growing speculations about intermediary figures but firmly maintained with a strong commitment to the one God of Israel as ever before" (Lee Aquila H. I., From Messiah to Preexistent Son. Jesus' Self-Consciousness and Early Christian Exegesis of Messianic Psalms, Mohr Siebeck: Tübingen 2005, 25).
} 
refers to a specific sequence of the meal as it was and is common to Judaism, but has been inverted by the pagan Christians in the same way they turned the Messiah to being a sacrifice. While in the Didache the berachoth, i.e., the benediction of the cup came first and then the benediction of the bread - exactly in the same way as the berachot during the Shabbat meal ${ }^{65}$-, the pagan-Christian community of Corinth had the benediction of the bread first and then the benediction of the wine (1 Cor 11:23-25) and transferred the significance of Jesus' death into a ritual dimension of a sacrifice (Beale \& Carson, 2007, p. 736). Again, this fact points to an opposition already mentioned, the opposition between the commitment of the Messiah on the one hand and Jesus' interpretation as a sacrifice, and also to the impossibility to interpret the Greek hero Jesus as a Jewish Messiah. He was either a hero or he was a Messiah; he belonged either to the Greeks or he belonged to the Jews. ${ }^{66}$ What Paul did was to refer to texts of the Exodus tradition and of the second Isaiah, to de-contextualize them, contextualize them anew in his way, and create a literary arrangement that fit to the pagans as well as to their fundamental lack of knowledge of the historical Jesus, a lack Paul and his communities had in common. That is why Paul's authoritative affirmation that he wrote about what "I have received of the Lord" (1 Cor 11:23) was not connected to Jesus' own life and practice, but to Paul's vision; thus, this vision enforced also the matter of the order of the Eucharistic meal.

The Didache can be considered a counterpart of a Jewish-Christian community to Paul's writings to pagan-Christian communities. Believing in the Davidic Messiah is the very center of this document, expecting him in the nearest future its very atmosphere. By then, all will be gathered within the community of the Messiah. The protagonist of this fulfillment will be God alone, and it will be revealed and manifest with and through the Messiah Jesus. That is why those Jewish Christians thanked God for the Messiah.

The Didache contains the purest mode of the belief in the Messiah of early Jewish-Christianity. It kept its faith because of three reasons. Firstly, the ceremonies of the community were close to Jesus' time, and maybe they even rooted in Jesus' own practice. Secondly, the time interval between Jesus and the community of the Didache could not have been a long one, because otherwise the community could hardly have been able to keep its clear commitment to the Davidic Messiah; at least it would have been eradicated by the destruction of the Temple in Jerusalem. Thirdy, the Didache is an exclusively Jewish-Christian writing, even if we do have its words only in Greek language; and that is why the Didache must be considered part and witness of the immediate Jesus tradition. It reveals messianic spirit that had not yet been altered by pagan myths of Jesus as a sacrifice. The essence of the Didache in concern of the Eucharist ceremony is absolutely clear, does not hide any obscure elements, and can be considered as a document that followed the same guidelines as Rabbinic Judaism when it comes to central parts of Jewish faith that can be found within the Torah: "The Torah uses common expression." 67

But the text of the Didache got lost and together with it the community ceased to exist due to some bad reasons. The Davidic Messiah did not appear and so the problem of committing Jesus as Davidic Messiah remained. This conflicting commitment could only be kept by altering it, transforming it, or by neglecting it.

\footnotetext{
${ }^{65}$ The Book of Blessing. For Shabbath and Holidays with the Family. Includes Questions and Answers. Includes the Passover Haggadah, Kfar HaOranim: Matan Arts Publishers Ltd. 2009, $22-25$.

${ }^{66}$ One cannot claim that Paul in Gal 3:28 wrote, "There is neither Jew nor Greek, there is neither bond nor free, there is neither male nor female: for ye are all one in Christ Jesus", for this was written out of a strict messianic hope and expectation, but had never in mind a process of a long run starting in these days and leading to fundamental transformations of the religious meaning of the man from Nazareth.

${ }^{67}$ Kethuboth 67b; Jebamoth 71a.
} 
This immanent problem of the early Jewish-Christian faith and its slow, but steady breakdown helped to overcome another problem connected to the growing number of pagan-Christian communities: The pressure to explain to them what they did not have a sensorium for or a helpful tradition decreased together with the fact that it became more and more difficult to keep the messianic commitment alive within the Jewish-Christian communities as time went on. The affirmation of Jesus as Davidic Messiah began to reel.

In the end Christianity, turned away from these Messianic ideas of Jewish-Christian communities and replaced them by an idea that stemmed from pagan religious stories and pagan philosophy. ${ }^{68}$ In this way, the God-man Jesus was "stripped of his Jewishness." ${ }^{69}$ It was the Council of Nicaea in 325 CE that accomplished this development and gave way to a kind of Christian religion that was both, a new religion turning against Judaism as such, and the foundation not of the Messianic age and the ruler ship of the Christ, but of the Roman Empire which has been demonstrating its power all the way since the time, when it killed the Messiah of Nazareth, up to those days of the $4^{\text {th }}$ cent., when it linked the well-known and well-practiced idea of a God-man to what has become the most central feature of Christian faith. This idea replaced what was experienced as the messianic ineffectiveness ever since Jesus's days by the Emperor's real power in order to enforce the declaration of the essential identity of God and Jesus.

Looking back at the very beginnings of the Christian movement, one might ask what Jesus might have thought of all that. ${ }^{70}$ And taking a look at the present, fundamental questions arise: How will it be possible to turn back again to Jesus the Messiah although his being Messiah was set aside and denied by the dogmatic-Christological teaching of the Church? And which kind of Messiah might he really have been? These two questions include a burning one connected to the annihilation of Jews in Europe during the time of the Shoa: Will Christianity really be able and willing to overcome its long-lasting anti-Judaic attitudes by going beyond its paganly founded Christological teaching that was enforced by holding that it was demanded and set up by divine authority? Since the killing of millions of Jews did happen in Christian countries that were soaked with the strong connection between the image of Christ as God-man and the hatred against Jews leading to strong measures against them in the Catholic tradition ${ }^{71}$ as well as in the Lutheran ${ }^{72}$ and others, it is more than just a theological question to exceed these dogmatic limits. It is a question concerning the self-description of Christianity and its human, moral and political effects in present and future.

\section{References}

Beale, G. K., \& Carson, D. A. (2007). Commentary on the new testament use of the old testament. Grand Rapids: Baker Academics.

Bockmuehl, M. (2013). The son of David and the Gospel. In D. Rudolph, \& J. Willits (Eds.), Introduction to the Messianic Judaism: Its Ecclesial context and biblical foundation (pp. 264-272). Zondervan: Grand Rapids.

Fackenheim, E. (1994). To mend the world: Foundations of Post-Holocaust Jewish thought. Bloomington-Indianapolis: Indiana University Press.

\footnotetext{
${ }^{68}$ Rubenstein Richard E., When Jesus Became God. The Struggle to define Christianity during the Last Days of Rome, Orlando et al. 1999, 79-84, 118 .

69 Boteach Shmuley, Kosher Jesus, Jerusalem / New York 2012, 197.

${ }^{70}$ Sandoz Ellis, Philosophical Anthropology and Dostoevsky's "Legend of the Grand Inquisitor", in: Avramenko Richard / Trepanier Lee (ed.), Dostoevsky's Political Thought, Plymouth: Lexington Books 2013, 93-113, esp. 94-103; Rubenstein Richard E., When Jesus Became God. The Struggle to define Christianity during the Last Days of Rome, Orlando et al. $1999,119$.

${ }_{71}$ One of the most prominent Councils demanding measures against the Jews was the $4^{\text {th }}$ Council of Lateran in 1215 and it canons 67-70 (http://www.ewtn.com/library/councils/lateran4.htm (Oct. 27 $\left.{ }^{\text {th }}, 2017\right)$ ).

72 Martin Luther's pamphlet "The Jews and Their Lies" (1543) was one of the most severe and long-lasting attacks against Jews https://sourcebooks.fordham.edu/source/_luther-jews.asp (Oct. 27th, 2017).
} 
Fredriksen, P. (2000). Jesus of Nazareth, King of Jews: A Jewish life and the emergence of Christianity. New York: Vintage Books.

Freyne, S. (2014). The Jesus movement and its expansion: Meaning and mission. Grand Rapids: Wlliam B. Eerdmans Publishing Company.

Harink, D. (2013). Jewish Priority, election, and the Gospel. In D. Rudolph, \& J. Willits (Eds.), Introduction to the Messianic Judaism: Its Ecclesial context and biblical foundation (pp. 273-281). Zondervan: Grand Rapids.

Klinghoffer, D. (2005). Why the Jews rejected Jesus: The turning point in Western history. New York: Doubleday.

Vermes, G. (2012). Christian beginnings: From Nazareth to Nicaea. New Haven-London: Yale University Press.

Wilson, T. A. (2013). The supersession and superfluity of the law? Another look at Galatians. In D. Rudolph, \& J. Willits (Eds.), Introduction to the Messianic Judaism:. Its Ecclesial context and biblical foundation (pp. 235-244). Zondervan: Grand Rapids. 